\title{
GREEN INFRASTRUCTURE CONTRIBUTION FOR CLIMATE CHANGE ADAPTATION IN URBAN LANDSCAPE CONTEXT
}

\author{
RAMYAR, R. - ZARGHAMI, E. \\ Faculty of Architecture and Urban Planning, Shahid Rajaee Teacher Training University \\ Tehran, Iran (e-mail: Reza.Ramyar@gmail.com) \\ *Corresponding author \\ e-mail: es.zarghami@gmail.com; phone: +98-912-1064467
}

(Received $11^{\text {th }}$ Nov 2016; accepted $9^{\text {th }}$ Mar 2017)

\begin{abstract}
Green infrastructure is strategic and spatial approach to landscape and environment planning, applying key principles of landscape ecology to urban environments, and specifically planning in multiscale approach. It is adopted and developed as a result of the opportunities it has provided in various disciplines to meet ecological, environmental, social challenges of landscape planning. Multi use of green infrastructure has the potential of contributing to climate change adaptation in various scales and regions. Climate change as a result of historical emissions of greenhouse gases would jeopardize cities. The deficiency of existing urban systems to cope with the risks resulting from these changes such as floods, droughts and extreme temperatures (intensification of the urban island heat effect), render residents of cities vulnerable to these changes. Green infrastructure by providing a range of ecosystem services has a significant role to play in helping to combat climate change. In this paper, it is investigated how and in what function and services, Green infrastructure strategy can help us in adopting to climate change in urban landscape context. At the first step, we classified the methods, principle and impacts on these two strategies (climate change adaptation and green infrastructure) to compare them. Then through this comparison, a conceptual model is developed clarifying their complementarity and relationship.
\end{abstract}

Keywords: ecosystem services, multi-scale approcach, landscape planning, urban ecology

\section{Introduction}

In urban planning and design, landscape planning and design, ecological science, social science and even economy, the trace of green infrastructure can be seen nowadays, despite the fact that some scholars believe it is a redevelopment of existing concepts relating to landscape and environment planning (Davies et al., 2006). Through the term of "multi-functionality", this approach presents the integration and interaction of different services and benefits on the same piece of land, which could deliver many functions through appropriate management. As an ecological approach of environment planning, it is also defined as an interconnected network of green spaces to conserve ecological values and functions of environment which simultaneously provides benefits to human populations (Liquete et al., 2015). this conservational planning approach is tested in continuation of knowledge and different approaches, for that planning is provided and in which through a systemic approach and in a larger scale to achieve multi-scale and multi-functional objectives, landscape is considered (McDonald et al., 2005). This interconnected network of ecological infrastructures includes natural areas e.g waterways, wetlands, woodlands, wildlife habitats, forests and also urban landscapes including greenways, parks, working farms, ranches, urban forests and other conservation lands protect our life (Benedict et al., 2006). It is an environmentally as well as economically viable approach for natural resource protection, ecosystem services production and water management (Dunn, 2010) which protects native species, maintains natural ecological processes, sustains air and water resources and contributes 
to the health and quality of our life (Matthews et al., 2015). Moreover, Multi-scale and multifunction planning and management of distinctive biophysical features of the urban environments can play an influential role in urban adaptation to climate change (Emmanuel et al., 2015).

The diversity in what constitutes green infrastructure and what it is allocated in planning provides a broad scope for its discussion and its use and make it vague to define it and to find its element, principle or the range of spaces (form and location) and resources that is proposed for green infrastructure to include. This vagueness also affects investigation of its influences on climate change adaptation. These highlight two primary questions discussed in this paper: which concepts actually constitute green infrastructure and how these ideas are articulated, and how can they be related to each other in a structure for landscape planning practice to provide an adaptation strategy? Here at the first step, we explore the academic and institutional researches done in this field, and then climate change adaptation is briefly explained. Finally, it is tried to set a structure from the efforts and researches done in green infrastructure planning facilitating its uses as an integrated way of planning in adapting to climate change.

\section{Adapting cities to climate change}

The general cause of climate change is the imbalance between energy that Earth receives from Sun (light and ultraviolet radiation) and the energy reflected back to the space (infrared energy) (IPCC, 2014). The amount of Greenhouse gases emission raise in Earth atmosphere induced by nature or human have changed climate system balance. This change leads to two significant changes in climate which are considered as the main reason behind other changes in Earth ecological situation; the first one is temperature raise that includes warmer seasonal temperatures and then increase in annual mean temperatures and warm days and decline in cold days. The second is changes in precipitation that includes reduction in the long-term snowfall and precipitation levels in hot tropical climate and increase in precipitation levels in humid climate zones (City of Moncton, 2013).

These two changes cause extreme weather events and also have some hazardous consequence known as climate change; flood, drought and drinking water shortage, severe winter storm, soil erosion, sea-level rise, temperature rise and urban heat islands, food security and shortages, pollution (soil and water) inversion and haze, water/sewer contamination, increase of forest fires, landslide, loss of species and biodiversity. Around the world, all countries are expected to feel the effects of climate change, although the specific impacts vary. The impacts, however, are expected to disproportionately affect those countries that already are at risk. Mitigation and adaptation are two main policies being contrived in dealing with climate change. The main goal of mitigating strategies through stabilization of atmospheric greenhouse gas concentration is preventing dangerous interference with climate system (Sussams et al., 2015). Adaptation is defined as adjustment in natural or humane systems in response to actual or expected climatic stimuli or their effects strategies that moderates harm or exploits beneficial opportunities (IPCC, 2013). The main goal of climate adaptation strategies is mandating or facilitating changes in socio-economic systems to reduce vulnerability of ecosystem to climate change (IPCC, 2013). Moreover, strengthening the climate resilience is known as the main goals on adaptation or mitigation strategies that 
along with other basic characteristic of all adaptation plans or strategies are summarized in the following section.

\section{Main characteristics of adaptation}

Strengthening social, ecological and economic resilience

Urban systems are mainly affected by global growth dynamics and this not only increases their exposure to ecological pressures, but also economic and social pressures. Resilience thinking provides a framework for viewing a social-ecological and economical system as one system operating over many linked scales of time and space (Pisano, 2012). As adaptation focuses on how the system changes and copes with disturbance, it uses resilience thinking as complement to sustainability. It also must have an integrative approach towards ecosystem planning and a plan for all influential features in order to protect critical ecosystem services on which humans depend. Therefore, integration and sustainability are two other goals in adaptive strategies along with improving resilience.

\section{Systematic understanding of processes}

Nature comprises human as part of environment, with the same importance of the other organism and elements along with them. In this holistic system, a change in any component will be reflected in the whole system. in ecology planning and design, systematic understanding of environment bring the abstract and mathematical sophistication of literature from physics and systems theory while its main idea is that the whole is more than the sum of constituent parts.

\section{Strategic approach}

Climate change adaptation is strategic because it is a multi-level plan to achieve a goal under conditions of uncertainty which includes several substances of skills, and engages many disciplines to fulfil the goal or goals. It shows how the goal (adaptation to climate change) could be achieved to shape the future in a desirable ends.

\section{Uncertainty in prediction, scenarios and plans}

Since adaptation planing associates with ongoing climate changes, it faces many limitations including uncertainty of scientific information and projections, future climatic projections, extent of materialization of projected future impacts, and cost of adaptation. Such obstacles have led many planners and policymakers unwilling to involve adaptation plans to their decisions in a confrontational and precise manner. Considering management actions and decisions as experiments with a priori hypotheses encourages them to outline small plans reducing information demand and uncertainty by learning through doing and monitoring them that becomes the key concepts and principles of adaptive management (Kato et al., 2008).

\section{Adaptive governance}

Adaptation needs a certain kind of governance that unites environmental and natural resource management approaches. Known as adaptive governance, this governance shares some or all of the following principles: polycentric and multi-layered institutions, participation and collaboration, self-organization and networks, and learning and 
innovation (Djalante et al., 2011). It will help in building and governing resilience along with coping with disturbance along with involvement of numerous stakeholders. The fact that climate change impacts cut across jurisdictional boundaries and the necessity of converging missions with various interests of stakeholders will require a widespread participations of governments, businesses, nongovernmental organizations, and individuals to minimize vulnerabilities and take advantage of potential planning opportunities (California Natural Resources Agency, 2016). This make adaptive specified governance as a special characteristic of adaptation.

\section{Adaptation principles}

\section{Vulnerability assessment and prioritizing the most vulnerable to climate change}

Vulnerability is the degree to which a system is susceptible to, and unable to cope with adverse effects of climate change and it is a function of the character, magnitude, and rate of climate change and variation to which a system is exposed, its sensitivity, and its adaptive capacity (City of Moncton, 2013). It could be defined through three terms of exposure, sensitivity and adaptation capacity. In adaptation plans, prioritizing can help to prioritize people, places and infrastructure that are most vulnerable to climate change in implementations. In this way, risk management methods and tools incorporate to help identification, assessment and prioritization of options to reduce vulnerability to potential environmental, social and economic implications of climate change.

\section{Using the best available science and flexibility in decisions}

Due to many uncertainties, adaptation should be grounded in the best available scientific understanding of climate change risks, impacts and vulnerabilities (EPA, 2012). Institutions also need to be ready to access and accept the best available science and information from regional to site-specific scales. Sensitivity to feedbacks and flexibility in response to future change helps them to significantly reduce the cost of anticipated climate impacts and to maintain relevance and currency of plans and programs over time. It supports continuous genuine adaptation.

\section{Building strong partnerships and overlap in governance}

Coordination across multiple sectors, overlapping institutions' responses and redundancy in institutions increase diversity and flexibility strategies that foster a strong awareness and response to cross-scale influences (EPA, 2012). This principle as a part of adaptive governance would enhance the vigour of system in coping with disasters.

\section{Cooperative and collaborative management and participation}

Devolution of management rights and power through participation empowers adaptive governance and and make it flexible and a system for decision-making according community viewpoints. This flexibility comes from allowance for learning from experiments tailored to specific places and situations. Adaptive co-management governance relies on the collaboration of a diverse set of stakeholders, operating at different levels from local users to municipalities, to regional and national organizations, and also to international bodies and combines dynamic learning characteristic of adaptive management (EPA, 2012). It is also depends on people's knowledge and awareness that makes education as a part of this principle. Moreover, 
their adaptive capacity (depending on trust, strong networks, and leadership) of socialecological systems is strongly connected to the capacity of the people in that system to respond, together and effectively, to change any disturbance.

\section{Having multi-scale approach and maximizing mutual benefits}

As climate change may have multi-scale effect, so it requires coordination across multiple scales that maximizes ecosystem adaptation benefits and also brings coordination in planning and enhances resilience capacity of communities. It helps to create strategies, where possible, that complement or directly support other related climate or environmental initiatives, such as efforts to improve disaster preparedness, promote sustainable resource management, and reduce greenhouse gas emissions including the development of cost-effective technologies (EPA, 2012).

\section{Continuous monitoring and evaluating the performance}

Adaptation strategies are complemented by systematic integration of monitoring at multiple points in the planning process which is the principal innovation in the proposed adaptive planning method. It would be a valuable tool for continuously assessing the effectiveness of a plan to determine whether it has achieved desired effects and provides sufficient information to stakeholders, policymakers and planners to revise a plan (Kato et al., 2008).

\section{Environment and adaptation justice}

Certain groups of people or certain countries will be affected by climate change more than others and become more vulnerable to disasters, depending on their ability to cope with different climate disasters, their access to resources and where they live. Therefore, policies and actions in adaptive action might guarantee social justice and be able to generate a sustainable community with the focus on the rights and basic needs. They must reduce or remove inequalities in access to urban services, and combat speculation and privatization of natural resources. This would be facilitated through democratic management and the society participation in policy or decision-making and monitoring process.

\section{Urban planning and design features in adaptation strategies}

As the main climate change drivers, change in precipitation and temperature causes many extreme and unpredictable climatic events. to deal with these events in terms of the origin features they struck, some researches and adaptive action fields are defined; water management (in response to water shortage and flood), air quality (in response to pollution, inversion and haze), temperature and human thermal comfort improvement (in response to temperature raise and urban heat islands), public health (in response to temperature raise, new climate change caused disease), biodiversity (in response to loss of species and biodiversity), fossil fuel consumption, agriculture (in response to food security and shortages), forest fires, sea-level rise, infrastructure (road, transport and...). They constitute main features of adaptive strategies. Below table (Table 1) summarizes all layers and items (include goals, main characteristics, principles and features) of climate change adaptation strategy. Resilience, sustainability and integration are defined as the main goals of adaptation strategies and main characteristics, principle and features of them summarized. 
Table 1. Goals, characteristics, principles and features regarding climate change

\begin{tabular}{|c|c|c|c|c|c|}
\hline \multicolumn{3}{|c|}{ Goals } & Approaches & Principles & Functions and Features \\
\hline 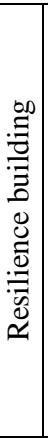 & 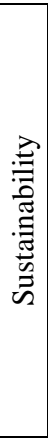 & 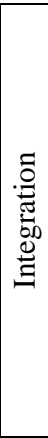 & $\begin{array}{c}\text { Systematic understanding } \\
\text { of processes } \\
\text { Strategic approach } \\
\text { Uncertainty in prediction } \\
\text { and scenarios } \\
\text { Adaptive Governance }\end{array}$ & $\begin{array}{c}\text { Vulnerability assessment and } \\
\text { prioritizing. } \\
\text { Using the best available science. } \\
\text { Partnerships and overlap in } \\
\text { governance. } \\
\text { Collaborative management and } \\
\text { participation. } \\
\text { Multi-scale approach. } \\
\text { Continuous monitoring and } \\
\text { evaluating. } \\
\text { Environment and adaptation } \\
\text { justice. }\end{array}$ & $\begin{array}{c}\text { Air quality } \\
\text { Water (shortage) management } \\
\text { Human thermal comfort } \\
\text { improvement } \\
\text { Public health } \\
\text { Biodiversity } \\
\text { Fossil fuel consumption } \\
\text { Landslide } \\
\text { Agriculture } \\
\text { Forest fire } \\
\text { Flood and Sea level rise }\end{array}$ \\
\hline
\end{tabular}

\section{Adaptation strategies for climate change}

Adaptation is a multidisciplinary strategy and it is considered in various fields, scales and levels. Carter et al. (1974) have highlighted six general strategies for adapting climate change impacts; prevention of loss, tolerating loss, spreading or sharing loss, changing use or activity, changing location, and restoration. Along with these general strategies, any region formulate adaptation strategies is base on future scenarios and predictions of that region. Current climate change adaptation strategies are more related to the type of threats but generally they also focus on reducing carbon emission, notwithstanding these strategies are different from mitigating strategies whose aim is to reduce carbon emission. Here in following table (Table 2) to reach a basis to find contribution of green infrastructure and defined strategies and principles of this approach on adaptation, climate change threats and adaptation strategy in two general consequences (direct or indirect) and 9 kinds of main threats in urban context is explaines. In adapting to each threat, main essential strategies are presented. Based on the natural, social or environmental source of vulnerability, all the threats are divided. For each strategy an abbreviation is listed which would be used in the next table to imply the relationship between each strategy in the table and a related strategy in Table 4.

Table 2. Direct and indirect consequences of climate change

\begin{tabular}{|c|c|c|c|}
\hline 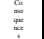 & \multicolumn{2}{|c|}{ Climate change threats } & Strategies \\
\hline \multirow{4}{*}{ 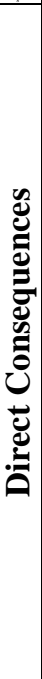 } & \multirow[t]{2}{*}{ 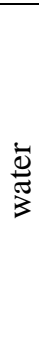 } & Water scarcity and Drought & $\begin{array}{l}\text { Long or short term water storage in any places }(\mathrm{W}-1) \text {. } \\
\text { Recycling and reusing water }(\mathrm{W}-2) \text {. } \\
\text { Reducing in water consumption }(\mathrm{W}-3) \text {. } \\
\text { Recharging or replenishing groundwater aquifers }(\mathrm{W}-4) \text {. } \\
\text { Pollutants transportation prevention to water resources }(\mathrm{W}-5) \text {. } \\
\text { Cloud seeding or any attempt to change the amount or type of precipitation or } \\
\text { any attempts to improving the chance of raining (W-6). }\end{array}$ \\
\hline & & $\begin{array}{l}\text { Flood, sea level rise and } \\
\text { Landslide }\end{array}$ & $\begin{array}{l}\text { Reduction of peak flow and increased duration of a flow event }(\mathrm{F}-1) \text {. } \\
\text { Reducing soil erosion and losses (F-2). } \\
\text { Water management in nearest place to precipitation against water traditional } \\
\text { management after collecting it (F-3). }\end{array}$ \\
\hline & \multirow[t]{2}{*}{$\exists$} & Temperature Raise & $\begin{array}{l}\text { Decreasing heat capacity of environment (T-1). } \\
\text { Facilitating wind flow across built environment (T-2). } \\
\text { Regulating temperature extremes through shade and wind and humidifies the air } \\
\text { (T-3). } \\
\text { Minimizing heat generation in environment (T-4). } \\
\text { Decreasing amount of green house gases as the main reason of temperature rise } \\
\text { (T-5). }\end{array}$ \\
\hline & & Dust storm & $\begin{array}{l}\text { Creating natural barriers against entrance passage of dust resources and control } \\
\text { their penetration to urban area (D-1). } \\
\text { Managing dust emission resources and controlling soil erosion (D-1). }\end{array}$ \\
\hline
\end{tabular}




\begin{tabular}{|c|c|c|c|c|}
\hline & & \multicolumn{2}{|c|}{ Inversion and Air pollution } & $\begin{array}{l}\text { Energy consumption reduction and lower energy demands (I-1). } \\
\text { Reduction in pollutant resources (I-2). } \\
\text { Carbon sequestration (I-3). } \\
\text { Air quality improvement and facilitating wind flow across built environment (I- } \\
\text { 4). }\end{array}$ \\
\hline & & \multicolumn{2}{|c|}{ Food shortage } & Localizing and improving food production in all possible spaces $(\mathrm{O}-1)$. \\
\hline & $\frac{\bar{\Xi}}{\bar{D}}$ & \multicolumn{2}{|l|}{ Plant } & $\begin{array}{l}\text { Creating various green spaces in various sizes in urbanized area as a proactive } \\
\text { approach }(\mathrm{P}-1) \text {. } \\
\text { Applying sustainable methods like xeriscaping that have resistance to extreme } \\
\text { weather }(\mathrm{P}-2) \text {. }\end{array}$ \\
\hline \multirow{2}{*}{ 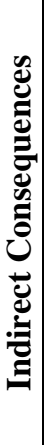 } & \multirow{2}{*}{ 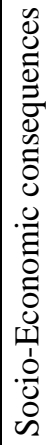 } & 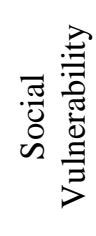 & $\begin{array}{l}\text { Unequal exposure to } \\
\text { risk. } \\
\text { Health and Wellbeing. }\end{array}$ & $\begin{array}{l}\text { Institution change (S-1). } \\
\text { Stakeholder participation enhancement (S-2). } \\
\text { Contribute to lifelong learning for the whole community to understand system } \\
\text { dynamics(S-3). } \\
\text { Support hands-on public environmental education and awareness (S-4). } \\
\text { Supporting policy objectives such as sustainable development, environmental } \\
\text { justice, social cohesion, or resilience (S-5). }\end{array}$ \\
\hline & & 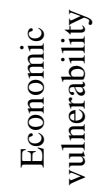 & $\begin{array}{l}\text { Poverty. } \\
\text { Financial personal or } \\
\text { social disadvantage. } \\
\text { Ecosystem Weakness } \\
\text { and fewer resources. }\end{array}$ & $\begin{array}{l}\text { Carefully and prudently using of natural resources (E-1). } \\
\text { Improving the capability of system to self-organizing and improve its robustness } \\
\text { (E-2). } \\
\text { Restructuring political economic ideologies and co-managing socio-economic } \\
\text { and ecologic systems (E-3). }\end{array}$ \\
\hline
\end{tabular}

\section{Green infrastructure planning}

The complexity of contemporary environmental problems like climate change, multiple scales across which they range and diversity of communities they affect has prompted numerous researchers to argue that traditional approach in planning, design governance, policymaking and decision making cannot, in isolation, effectively address these challenges. In response, in all various discipline many attempts has been made to cope with climate change and its problems. In this regard in the field if landscape planning and architecture also planning and design approaches has been adapted in response to future ecological problems especially climate change. Moreover, sustainable landscape planning, design and management are considered as one of essential disciplines in facilitating environments adaptation to climate change and also its sources mitigation. Landscape architecture, owing to its multifunctional characteristic and wide range of effects on ecosystem and its services can help mitigate and take advantage of climate changes.

Green infrastructure planning as an alternative and integrated approach in ecological landscape planning would have a significant potential in conveying adaptation actions (Abunnasr, 2013). Green infrastructure is predominantly a multi-scale planning approach to conservation and protection of land with ecological and cultural benefits. In this approach, various planning strategies are employed at different scales to develop an extensive network of green spaces. However, it is possible to identify underlying features, common principles and also characteristics of all the disciplines that use the term. Green infrastructure provides multiple services that include social, ecological, and economical benefits. Supporting, provisioning, and regulating environmental benefits or ecosystem services is the main focal point of the actions in this approach which are supplied with enlivening and ecological parts of our environment; water, soils, nutrients and organisms. These benefits can also led to storm water pollutant reductions, enhanced groundwater recharge (Emmanuel et al., 2015), protection of soil, increased carbon sequestration (McPaherson et al., 2008), climate change adaptation and 
mitigation (Emmanuel et al., 2015; Mell, 2016; Hamin et al., 2008), address flooding (Barnett et al., 2007) and improved air quality (EPA, 2012).

\section{Green infrastructure characteristics, principles features}

With the aims of enhancing the quality of life, place and environment across different scales and boundaries and improving the ability of ecosystem in coping with natural disasters or climate change, economic and social crises, resilience is defined as the main goal of green infrastructure planning approach (EPA, 2013). With this goal, the system's ability to absorb change and disturbance and its ability to maintain the same relationships between system populations or state variables after shocks must improve that make it necessary to consider improving resilience as the main goal in any action. It is necessary to increase system's vulnerability and forego emerging opportunities. This goal escalates the complexity of planning by shifting decisions and strategies from those whise aim is to control strategies change to manage the capacity of systems to cope with, adapt to and change them (Pisano, 2012). In general, resilience, sustainability and integration are three main goals which are at the heart of any principles and actions of green infrastructure and generally this approach. Broadly speaking, persistence needs building resilience capacity which depends on sustainability and both of them require integrity in action. Like climate change adaptation, there are some assumptions in green infrastructure which constitute its main structure; systematic understanding of processes and Strategic approach are two basic subjects which shape green infrastructure approach. According to many researches on green infrastructure, it can be said that it has three main principles (connectivity, conservation multifunctionality, and multi-scale and object approach) in in addition to two general principle which can be seen in all sustainable planning methodology currently include participation and justice. In this theory, principles and functions of landscapes are defined through its approach toward conservation and development, presented in the following table (Table 3):

- Multifunctionality: Improves the combination of ecological, social, and economic functions of green spaces.

- Connectivity: Improves the functional and physical connection between green spaces on different scales and from diverse perspectives.

- Multi-object approach: includes a variety of green and blue spaces (either natural or semi-natural, and public or private) and even developed parts and components which can be modified to act as green spaces (Hansen et al., 2014).

- Multi-scale approach: Considers all the scales in the decision, plans and initiatives from a single parcel to large areas of environment and community.

- Conservation: protects, restores and creates habitats and ensures all designated sites are conserved (Kambites et al., 2006).

Finally, along with principles and basis in green infrastructure, there are different elements which are included in this approach. In each if them, some concerns are discussed in various strategies which they are separately presented here for our reason:

- Wildlife and vegetation: biodiversity, biotic functions, abiotic functions, native species, habitat creation.

- Soil: biodiversity, erosion, soil fertility, plant specious, soil formation. 
- Land: urban sprawl, land fragmentation, topography, permeable and impermeable surfaces.

- Air pollution and temperature: air pollution, dust and haze reduction, urban heat island.

- Economy: value of green spaces, tourism, value of building, incomes and expenses, employment.

- Health: air pollution, physical activity, accessibility, temperature, environment noise, flood storage prevention, food production, climate regulation, recreation, nutrient cycling, air humidity.

- Culture and identity: participation, social capital, attachment, territory defence, aesthetics.

- Water: water management, irrigation, urban drainage system, fostering ground water, flood storage prevention, air humidity.

Table 3. Green infrastructure planning goals, approaches, principles and functions

\begin{tabular}{|c|c|c|c|c|c|c|c|c|}
\hline \multirow{2}{*}{\multicolumn{3}{|c|}{ Goals }} & \multirow{2}{*}{ Approaches } & \multicolumn{2}{|c|}{ Principles } & \multicolumn{3}{|c|}{ Functions and Features } \\
\hline & & & & Specific & General & Abiotic & Biotic & Cultural \\
\hline 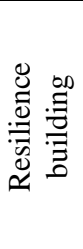 & 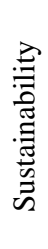 & 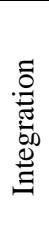 & $\begin{array}{l}\text { Systemic } \\
\text { Strategic }\end{array}$ & $\begin{array}{l}\text { Multifunctionality } \\
\text { Multi-Scale } \\
\text { planning } \\
\text { Multi-object } \\
\text { approach } \\
\text { Conservation } \\
\text { Connectivity }\end{array}$ & $\begin{array}{l}\text { Environment Justice } \\
\text { (in Generation, } \\
\text { Distribution and } \\
\text { Articulation) } \\
\text { Participation and } \\
\text { Education }\end{array}$ & $\begin{array}{l}\text { Soil } \\
\text { Water } \\
\text { Temperature } \\
\text { Land }\end{array}$ & $\begin{array}{l}\text { Fauna } \\
\text { Flora }\end{array}$ & $\begin{array}{l}\text { Aesthetic } \\
\text { Cultural } \\
\text { Identity } \\
\text { Health }\end{array}$ \\
\hline
\end{tabular}

In a changing climate, the functionality provided by urban green space becomes increasingly important to cope with consequent hazardous disasters. To identify the overlaps and contradictions between both fields, as the main aim of this paper and to set a basis for a decision support model, we examine various classifications to clarify their relationship. Here firstly main principles of green infrastructure in planning is subtracted from various researches in this field. Conservation, connectivity, and multifunctionality (along with multi-scale planning, multi-object approach) define main principles of green infrastructure they could be complemented with influential principle to improve resilience. According to Pisano (2012) self-organization and robustness along with connectivity could play an important role in maintaining general resilience here added to green infrastructure principles. These four principles could make an appropriate base point in defining its strategy to investigate their impacts on climate change adaptation and mitigation. The next table (Table 4) summarizes all possible strategies in each principle based on planning features and presents their impacts on adaptation and mitigation. Also, its relation to climate change strategy is presented, with an abbreviation defined in Table 2.

Apart from the principles and strategies of green infrastructure planning, green spaces or the natural environment have the potential to help adapt to climate change in cities. Green spaces in cities could help to reduce the volume of storm water. They could not only reduce air pollution and purify it but also encourage the flow of polluted air away from people and buildings. They can be adapted to cope with less potable water supplies by planting more drought-tolerant species, and use xeric style species and through storm water harvesting with water sensitive techniques could promote water management in response of drought and water shortage. They totally have some 
influential benefits in confronting with climate change without paying attention to planning approach. These benefits and some methods in landscape planning in facing climate change threats are summarized in Table 5. However, with ecological or conservational approach of planning like green infrastructure, coping with climate change could accommodate other benefits and services whcich are considered in such planning approaches. So in the following, it is presented how this approaches complement each other.

Table 4. Green infrastructure principles, strategies, and their impacts on climate change adaptation and mitigation

\begin{tabular}{|c|c|c|c|c|c|}
\hline \multirow{2}{*}{ 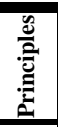 } & \multirow{2}{*}{\multicolumn{2}{|c|}{ Features }} & \multirow[b]{2}{*}{ Strategies } & \multicolumn{2}{|c|}{ Impacts on Climate Change } \\
\hline & & & & Adaptation & Mitigation \\
\hline \multirow{8}{*}{ 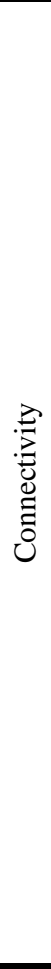 } & \multirow{5}{*}{ 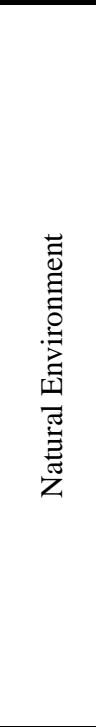 } & Water & $\begin{array}{l}\text { Securing continuous flow of streams to ensure } \\
\text { ecosystem empowerment from downstream to } \\
\text { upstream. } \\
\text { Flood alleviation by delaying the downstream } \\
\text { passage of flood flows, reducing the volume of } \\
\text { runoff, connecting the catchment to the receiving } \\
\text { landscape area, and promoting rainfall } \\
\text { infiltration into the soil. }\end{array}$ & $\begin{array}{l}\text { Drought and Water } \\
\text { scarcity (w-4) } \\
\text { Dust (D-2) } \\
\text { Flood (F-1) } \\
\text { Ecosystem weakness (E- } \\
\text { 2) }\end{array}$ & $X$ \\
\hline & & Air & $\begin{array}{l}\text { Maintaining or helping the continuous flow of } \\
\text { wind across the urban. }\end{array}$ & $\begin{array}{l}\text { Drought and Water } \\
\text { scarcity (w-6) } \\
\text { Temperature raise (T-2) } \\
\text { Inversion (I-4) }\end{array}$ & $\mathrm{X}$ \\
\hline & & Soil & - & $\mathrm{X}$ & $\mathrm{X}$ \\
\hline & & Flora & $\begin{array}{l}\text { Connecting green spaces and patches to improve } \\
\text { animal (like butterflies or birds) migration and } \\
\text { also plants pollination. }\end{array}$ & $\begin{array}{l}\text { Inversion and Air } \\
\text { pollution (I-4) } \\
\text { Dust (D-1) } \\
\text { Temperature raise (T-2,5) } \\
\text { Ecosystem weakness (E- } \\
\text { 2) } \\
\end{array}$ & $\checkmark$ \\
\hline & & Fauna & $\begin{array}{l}\begin{array}{l}\text { Facilitating animal movement and nutrient } \\
\text { dispersal. }\end{array} \\
\end{array}$ & $\begin{array}{l}\text { Ecosystem weakness (E- } \\
\text { 2) }\end{array}$ & $X$ \\
\hline & \multirow{2}{*}{ 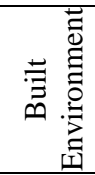 } & Surfaces & - & $\mathrm{X}$ & $\mathrm{X}$ \\
\hline & & $\begin{array}{l}\text { Urban } \\
\text { form }\end{array}$ & $\begin{array}{l}\text { Managing urban form to maximize wind flow } \\
\text { and wildlife migration. }\end{array}$ & $\begin{array}{l}\text { Temperature raise (T-2) } \\
\text { Inversion and Air } \\
\text { pollution (I-4) }\end{array}$ & $\mathrm{X}$ \\
\hline & Human & Human & $\begin{array}{l}\text { Improving people interconnection and their } \\
\text { connection to nature. }\end{array}$ & \begin{tabular}{|l|} 
Ecosystem weakness (S- \\
2)
\end{tabular} & $\checkmark$ \\
\hline \multirow{4}{*}{ 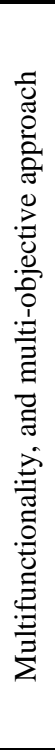 } & \multirow{4}{*}{ 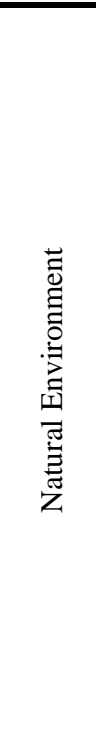 } & Water & $\begin{array}{l}\text { Water management in all its forms (vapour, } \\
\text { moisture, stream or water way) and related } \\
\text { ecological functions: Water storage, Silt } \\
\text { removal, Pollutant treatment, Infiltration, } \\
\text { Biodiversity, Visual amenity, Play, Education, } \\
\text { Embodied, energy }\end{array}$ & $\begin{array}{l}\text { Temperature raise (T-3) } \\
\text { Drought (W 1,2,4,5,6) } \\
\text { Flood (F1,3) } \\
\text { Food Shortage (O-1) } \\
\text { Dust (D-2) } \\
\text { Ecosystem weakness (E- } \\
\text { 1) } \\
\end{array}$ & $\checkmark$ \\
\hline & & Air & - & $\mathrm{X}$ & $\mathrm{X}$ \\
\hline & & Soil & $\begin{array}{l}\text { Conserving soil's natural structure and managing } \\
\text { this important natural substance for multipurpose } \\
\text { provision of ecosystem service. }\end{array}$ & \begin{tabular}{|l|} 
Dust (D-2) \\
Landslide (F-2) \\
Ecosystem weakness (E- \\
1) \\
\end{tabular} & $\mathrm{X}$ \\
\hline & & Flora & $\begin{array}{l}\text { Improving ecosystem services and utilizing } \\
\text { diverse services through the habitat and plant } \\
\text { management. }\end{array}$ & \begin{tabular}{|l} 
Drought and Water \\
scarcity $(\mathrm{W}-6)$ \\
Dust (D-1,2) \\
Flood and Landslide(F-1) \\
Food Shortage $(\mathrm{O}-1)$ \\
Temperature raise (T- \\
$1,3,5)$ \\
Inversion and Air \\
pollution (I-1,3) \\
Ecosystem weakness(E- \\
$2)$
\end{tabular} & $\checkmark$ \\
\hline
\end{tabular}




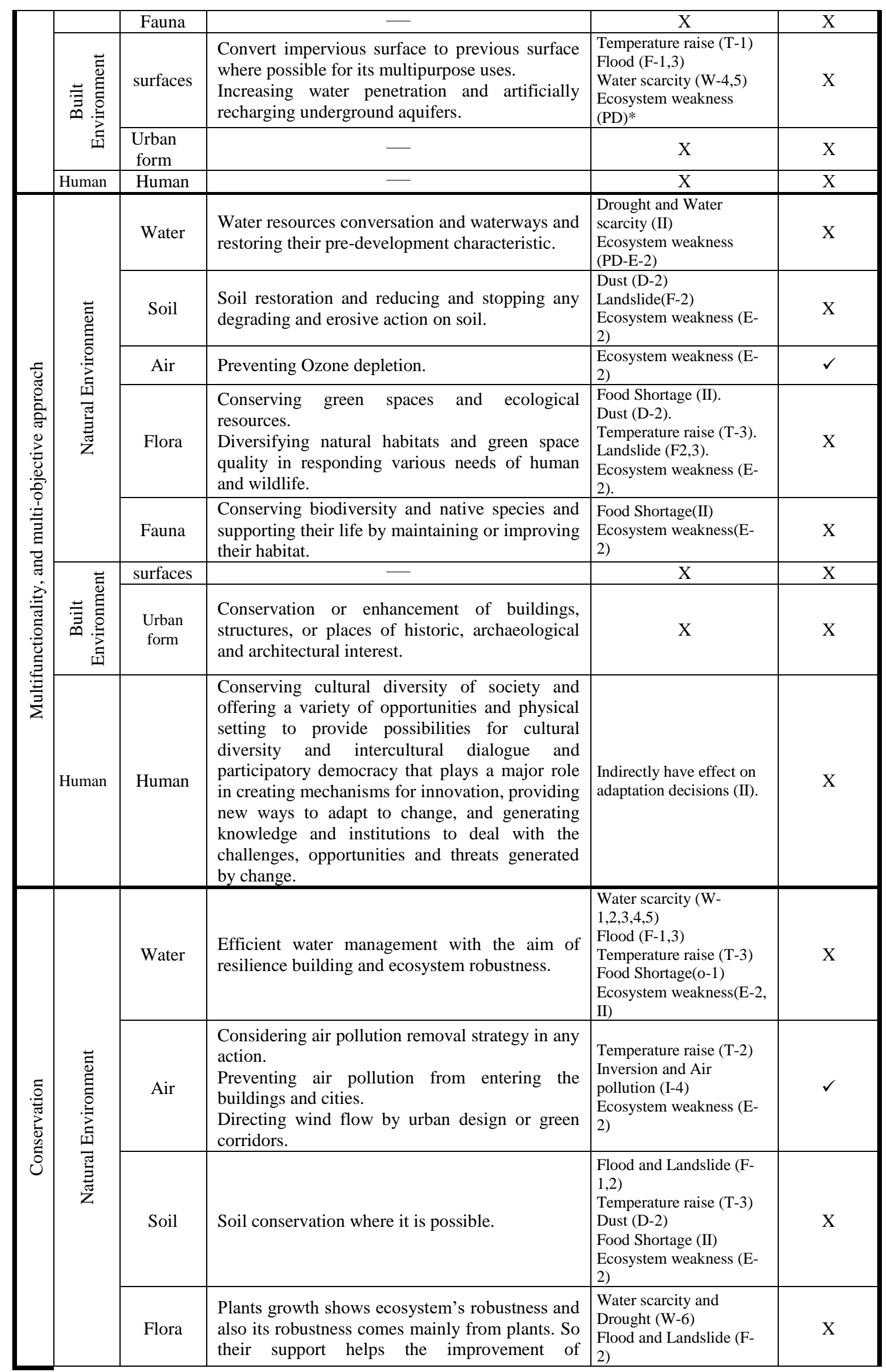




\begin{tabular}{|c|c|c|c|c|}
\hline & & ecosystem. & $\begin{array}{l}\text { Temperature raise (T-3,5) } \\
\text { Inversion and Air } \\
\text { pollution (I2,3,4) } \\
\text { Dust (D-2) } \\
\text { Food Shortage(II) } \\
\text { Ecosystem weakness (E- } \\
\text { 2) } \\
\text { Plant vulnerability (P-1,2) }\end{array}$ & \\
\hline & Fauna & $\begin{array}{l}\text { Considering life cycle of creatures and } \\
\text { biodiversity can build and improve ecosystem } \\
\text { capacity and its autonomy. }\end{array}$ & $\begin{array}{l}\text { Food Shortage(II) } \\
\text { Ecosystem weakness (E- } \\
\text { 2) }\end{array}$ & $\mathrm{X}$ \\
\hline \multirow[b]{2}{*}{ 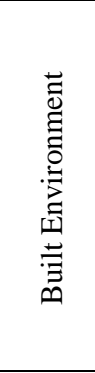 } & Surfaces & - & $X$ & $\mathrm{X}$ \\
\hline & $\begin{array}{l}\text { Urban } \\
\text { form }\end{array}$ & $\begin{array}{l}\text { Making changes possible on built environment } \\
\text { (on its material, form or shape) to provide an } \\
\text { environment resemble to its natural position (like } \\
\text { before development position) or improve it by } \\
\text { adding built structure which can reform it. }\end{array}$ & \begin{tabular}{|l|} 
Temperature raise $(\mathrm{T}-$ \\
$1,2,3)$ \\
Water scarcity and \\
Drought (W-1) \\
Inversion and Air \\
pollution (I-4) \\
Flood (F-3) \\
Food Shortage (O-1) \\
Ecosystem weakness(E- \\
2,S-2) \\
\end{tabular} & $\checkmark$ \\
\hline Human & Human & $\begin{array}{l}\text { Improving civic participation by offering an } \\
\text { institutional base for groups and individuals to } \\
\text { meet and interact and educate them in } \\
\text { participation processes. }\end{array}$ & $\begin{array}{l}\text { Indirectly have effect on } \\
\text { adaptation decisions (II). }\end{array}$ & $\checkmark$ \\
\hline
\end{tabular}

*- II means indirect Impacts, PD means maintaining predevelopment situation and other abbreviation come from Table 2.

Table 5. Green structures benefits in facing climate change threats

\begin{tabular}{|c|c|c|}
\hline $\begin{array}{c}\text { GI } \\
\text { Benefit }\end{array}$ & Climate Change Threats & Methods that GI could alleviate changes \\
\hline 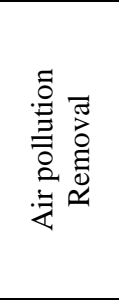 & $\begin{array}{l}\text { Air quality strongly depends on } \\
\text { weather and researches show that it } \\
\text { will exacerbate in future climate } \\
\text { change due to a weaker global } \\
\text { circulation and a decreasing } \\
\text { frequency of mid-latitude cyclones } \\
\text { (Jacob and Winner, 2009). }\end{array}$ & $\begin{array}{l}\text { - Driving the polluted air upwards or out of residential areas } \\
\text { (by corridors and barriers) } \\
\text { - Make barriers like green belt against penetrating pollutant air } \\
\text { or dust storms from out of city. } \\
\text { - Decrease air pollution source through reduction in fossil fuel } \\
\text { consumption by land use planning (reduction in traffics) and } \\
\text { creating micro climate (by green structure) } \\
\text { - Removing air pollution and carbon sequestration. }\end{array}$ \\
\hline 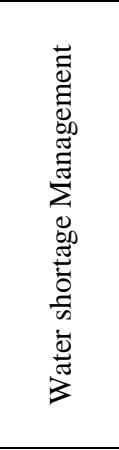 & $\begin{array}{l}\text { Extended dry periods over the last } \\
\text { decades have reduced water } \\
\text { availability and placed pressure on } \\
\text { city water resources. } \\
\text { High temperature and drought } \\
\text { increase water scarcity. }\end{array}$ & $\begin{array}{l}\text { - Reduction in water consumption (by using xeric style } \\
\text { landscape or drought-tolerant species). } \\
\text { - Artificially recharging underground aquifers (by infiltrating } \\
\text { storm water through permeable media or via direct injection). } \\
\text { - Urban water cycle management and reusing water in various } \\
\text { situations. } \\
\text { - Water management in micro-scale, restoring it at local-scale } \\
\text { and preventing its pollution (by WSUD or LID techniques). } \\
\text { - Managing water resources and preventing their pollution. } \\
\text { - Predicting future climate with scenarios or models and } \\
\text { finding proper and efficient species for future situation of the } \\
\text { regions. }\end{array}$ \\
\hline 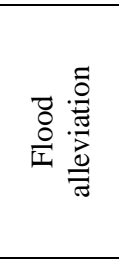 & $\begin{array}{l}\text { Extreme precipitation events } \\
\text { increase the threat of flood and its } \\
\text { frequency in cities. Flood disrupt } \\
\text { public water supply and sewer } \\
\text { systems, transport, commerce, and } \\
\text { economic activity, and damage } \\
\text { physical assets and infrastructure }\end{array}$ & $\begin{array}{l}\text { - Source control like upland land management } \\
\text { - Run-off reduction by increase in impervious surface, storing } \\
\text { water in green structures like trees, green roofs or walls. } \\
\text { - Diversion of flood flows away from affected areas. }\end{array}$ \\
\hline
\end{tabular}




\begin{tabular}{|c|c|c|}
\hline 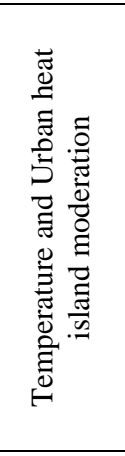 & $\begin{array}{l}\text { Temperature raise predicted to be } \\
\text { the main impact of climate change. }\end{array}$ & $\begin{array}{l}\text { - Maximizing the cooling potential of existing green } \\
\text { infrastructure (maintain healthy vegetation by the help of } \\
\text { WUSD). } \\
\text { - Maximizing cooling via evapotranspiration (WUSD pervious } \\
\text { surface). } \\
\text { - Maximizing cooling via shading. } \\
\text { - Managing and maximizing green corridors. } \\
\text { - Minimizing the exposed surface to great amounts of sun } \\
\text { radiation by the help of techniques like green walls or roofs. } \\
\text { - Compiling information about the area's topography, climate } \\
\text { and land use for precise planning in urban context (increasing } \\
\text { wind speed in urban context). }\end{array}$ \\
\hline 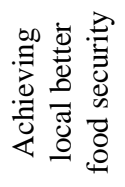 & $\begin{array}{l}\text { Temperature raises and water } \\
\text { resource constraints will potentially } \\
\text { affect crop yields pest and weed } \\
\text { ranges and introduction, and the } \\
\text { length of the growing season. }\end{array}$ & $\begin{array}{l}\text { - Growing food and also flowers that improve biodiversity } \\
\text { - Employing various kind of green structures like community } \\
\text { gardens, and allotment areas or roof gardens and yards as a } \\
\text { valuable source of urban farming. }\end{array}$ \\
\hline 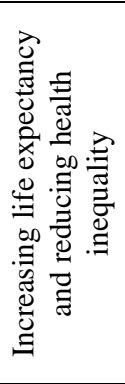 & $\begin{array}{l}\text { Weather conditions and climate } \\
\text { change affect air pollution or } \\
\text { exacerbate its effects and may affect } \\
\text { exposure to air pollutants through } \\
\text { change in biological patterns, } \\
\text { emissions and the distribution and } \\
\text { type of airborne material, which } \\
\text { cause allergies (UNDP, 2016,71). }\end{array}$ & $\begin{array}{l}\text { - The air quality improvement. } \\
\text { - Temperature reduction } \\
\text { - Flood reduction threats } \\
\text { - Removing air pollution } \\
\text { - Shading and improving heat comfort } \\
\text { - Improving people's sense of space and nature } \\
\text { - Recreation } \\
\text { - Creating playing field and encouraging people to exercise } \\
\text { - Helping to improve the wind flow across the cities with } \\
\text { landscape corridors. }\end{array}$ \\
\hline 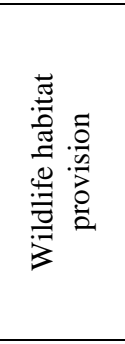 & $\begin{array}{l}\text { Forest fires, drought, flood, and } \\
\text { food shortage damage wildlife } \\
\text { habitats and exacerbate their fragile } \\
\text { situation. } \\
\text { The main result of these changes is } \\
\text { biodiversity loss. }\end{array}$ & $\begin{array}{l}\text { - Improving natural landscape features such as small water } \\
\text { bodies, green roofs, forest patches and hedgerows, which can } \\
\text { act as corridors or stepping stones. } \\
\text { - Improving open storm water system that provides a better } \\
\text { environment for local plants and wildlife. } \\
\text { - Using native species in plantation. } \\
\text { - Considering three layers on wildlife habitat on ground, } \\
\text { underground and above the ground in developments. } \\
\text { - Create safe area attracting birds and insects. }\end{array}$ \\
\hline 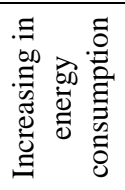 & $\begin{array}{l}\text { Increasing temperatures will add to } \\
\text { the demand for cooling, and the } \\
\text { impacts of extreme weather events } \\
\text { may affect electricity and energy } \\
\text { consumption. }\end{array}$ & $\begin{array}{l}\text { - Providing space for renewable energy like geothermal heat, } \\
\text { hydroelectric power, biomass and wind power. } \\
\text { - Creating microclimates (by shading, increasing in wind flow, } \\
\text { and evaporative cooling). } \\
\text { - Passive cooling of the buildings by green walls and roofs. }\end{array}$ \\
\hline
\end{tabular}

\section{Complementarity between green infrastructure and adaptation measures}

Above tables (1, 2, 3, and 4) shows how these two theories or strategies have many similarities. They are both ecosystem based and their main goals are common; sustainability or resilience. On the other hand, green infrastructure absolutely could improve adaptation which they complement each other (Figure 1). Green infrastructure could provide significant opportunities in creating spaces and environments which increase the community's resilience to climate change. All green infrastructure characteristics are involved in climate change. They both have strategic view and systemic approach. However, adaptive governance, uncertainty, and coping with climate change are other characteristics which are only seen in climate change adaptation strategies. In both strategies, some principles are defined that in them participation, justice and multi-scale approach is common in and other green infrastructure principles like connectivity and multifunctionality absolutely would have positive effect on climate change adaptation. In features layer, green infrastructure have 
many effects on climate change. Here some of main influences of green infrastructure approach toward climate change adaptation is highlighted. It is shown that it could be complemented by climate change adaptation. Cooperation of these two strategies can help in making an integrated model for urban development and ecological conservation plans with adaptation direction.
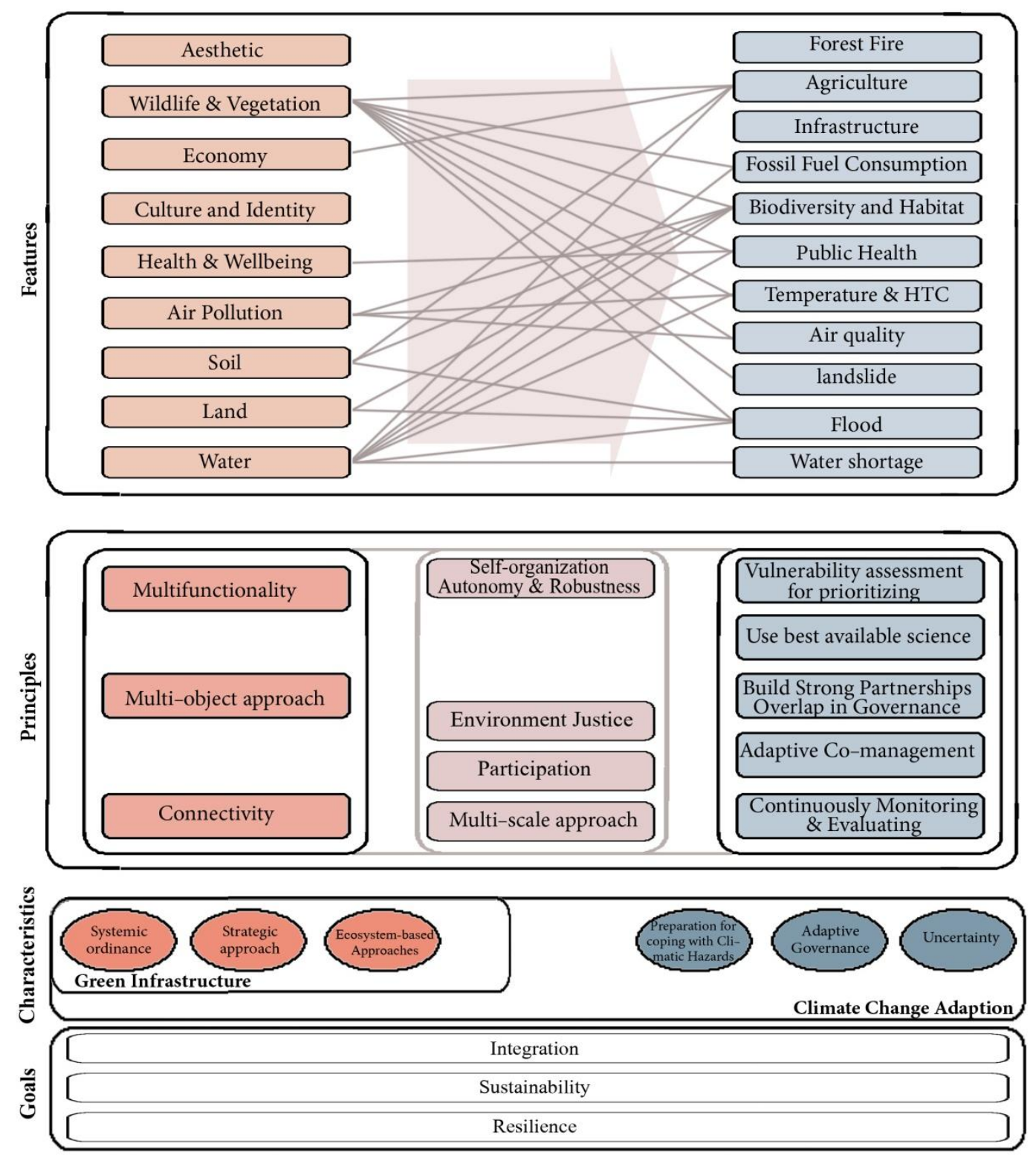

Figure 1. Complementarity between green infrastructure and adaptation measures

\section{Conclusion}

There is much evidence that many scientists and agencies or organizations use green infrastructure to address the ecosystem consequences of environmental pressure. In this respect, this multi-scale planning approach has an impressive contribution in ecological multi-scale connections between various ecological infrastructures offering the prospect of a more sustainable landscape for well-being, biodiversity and adaptability to climate 
change. This analysis demonstrates in which fields and for what purpose, it is used. It has proven that green infrastructure encompasses a number of issues based on the purposes of applying that. Although these issues may have more importance than a simple term, gathering under the umbrella of a term like green infrastructure could emphasize their interconnections and dependence on each other. Furthermore it highlights the necessity of having an integrated approach in planning on various scale, aspects and goals.

The aspect of green infrastructure contribution to climate change has begun to be discussed and documented (Mell, 2016). Yet, the extent and explicit contribution of green infrastructure has not been researched enough and there are few studies that systematically have reviewed, focused on this aspect. Maybe it is due to vagueness of these two concepts or maybe due to their immatureness in practice. Green infrastructure, owing to its multifunctional characteristic, can help to mitigate and/or take advantage of the mentioned impacts. There are many examples of climate change adaptation measures through green infrastructure e.g water management and regaining natural water cycle (flood storage, improvement of rainwater infiltration, reduction of run-off, and improvement of water quality), urban heat island mitigation (green corridor, pervious surfaces green roofs and walls or tree planting) and land-coverplanning. Unique role of green infrastructure in adapting to climate change is not attributable to its physical feature, but also in principles and also in strategic planning methods.

The main objective of this paper is to analyze the role of green infrastructure as a strategy or approach in planning and designing for adapting to climate change. This work has helped to understand the links between landscape in various scales and climate change. Green infrastructure has been described as the strategy for landscape planning and design. Climate change is described as important drivers of global change (Folke et al., 2016) and adaptation to it is about taking actions which will help to reduce the impacts associated with anticipated climate change trends, events and hazards. It is also about taking advantage of new opportunities hich may be created as a result of climate change (Barthel et al., 2013).

So understanding the relationship between climate change adaptation strategy and green infrastructure can be used in setting in a foundation for intelligently and effectively planning, designing and managing green area as the main fostering part of ecosystem. Here with reviewing what is highlighted and discussed in green infrastructure approach it attempts do set a clear model of their relationship and shows how these two strategies complement each other. This classification can facilitate the use of all these essential and substantial concepts in planning and also makes green infrastructure an integrated approach which also can be used in adaptation to climate change. Absolutely there are many factors, actors and drivers presented in inherently uncertain environment which also have effects on adaptation strategies not considered in this research. This complementarity relation between green infrastructure and climate change adaptation, however, requires further exploration to be applicable in experiences.

\section{REFERENCES}

[1] Abunnasr, Y.F. (2013): "Climate Change Adaptation: A Green Infrastructure Planning Framework for Resilient Urban Regions". - Dissertations. 
[2] Barthel, S., Isendahl, Ch. (2013): Urban gardens, agriculture, and water management: Sources of resilience for long-term food security in cities. - Ecological Economics 86: 224-234.

[3] Benedict, M. A., McMahon, E. D. (2006): Green Infrastructure: linking landscapes and communities. - Island Press, Washington.

[4] Barnett, J., Beckman, J. (2007): Coastal cities face rising seas. - Planning 73(8): 34-37.

[5] Carter, J.G. (2011): Climate change adaptation in European cities. - Current Opinion in Environmental Sustainability 3: 193-198.

[6] City of Moncton. (2013): Climate Change Adaptation and Flood Management Strategy. City of Moncton Corporate Climate Change Action Committee.

[7] California Natural Resources Agency. (2016): California Climate Change Adaptation Strategy.

[8] Davies, C., McGloin, C., MacFarlane, R., Roe, M. (2006): Green Infrastructure Planning Guide Project: Final Report. - NECF, Annfield Plain.

[9] Djalante, R., Holley, C., Thomalla, F. (2011): Adaptive Governance and Managing Resilience to Natural Hazards. - Int. J. Disaster Risk Sci. 2 (4):1-14.

[10] Dunn, A.D. (2010): Sitting Green Infrastructure: Legal and Policy Solutions to Alleviate Urban Poverty and Promote Health Communities. - Boston College Environmental Affairs Law Review 37(1):41-66.

[11] Emmanuel, R., Loconsole, A. (2015): Green infrastructure as an adaptation approach to tackling urban overheating in the Glasgow Clyde Valley Region, UK. - Landscape and Urban Planning 138: 71-86.

[12] EPA (U.S. Environmental Protection Agency). (2012): Climate Change Adaptation Plan. - Public Review Draft.

[13] Folke, C., Biggs, R., Norström, A. V., Reyers, B., Rockström, J. (2016): Socialecological resilience and biosphere-based sustainability science. - Ecology and Society 21(3):41.

[14] Jacob, D., Winner, D. (2009): Effect of climate change on air quality. - Atmospheric Environment 43(1): 51- 63. [Accessed 24th March 2010]. Available from: http://0www.sciencedirect.com

[15] Kambites, C., Owen, S. (2006): Renewed Prospects for Green Infrastructure Planning in the UK. - Planning, Practice and Research 21(4): 483 - 496.

[16] Hamin, E., Gurran, N. (2008): Urban form and climate change: Balancing adaptation and mitigation in the U.S. and Australia. - Habitat International 33: 238-245.

[17] Hansen, R., Pauleit S. (2014): From Multifunctionality to Multiple Ecosystem Services? A Conceptual Framework for Multifunctionality in Green. Infrastructure Planning for Urban Areas. - AMBIO 43: 516-529.

[18] IPCC. (2013): Climate Change 2013: The Physical Science Basis. - Cambridge University Press.

[19] IPCC. (2014): Climate Change 2014: Synthesis Report. Contribution of Working Groups I, II and III to the Fifth Assessment Report of the Intergovernmental Panel on Climate Change [Core Writing Team, R.K. Pachauri and L.A. Meyer (eds.)]. IPCC, Geneva, Switzerland.

[20] Kato, S., Ahern, J. (2008): "Learning by doing': adaptive planning as a strategy to address uncertainty in planning'. - Journal of Environmental Planning and Management 51(4): $543-559$.

[21] Liquete, C., Kleeschulte, S., Dige, G., Maes, J., Grizzetti, B., Olah, B., Zulian, G. (2015): Mapping green infrastructure based on ecosystem services and ecological networks: A Pan-European case study. - Environmental Science and Policy 54: 268-280,

[22] Matthews, T., Lo, A. Y., Byrne, J. A. (2015): Reconceptualizing green infrastructure for climate change adaptation: Barriers to adoption and drivers for uptake by spatial planners. - Landscape and Urban Planning 138: 155-163. 
[23] McDonald, L. A., Allen III, W. L., Benedictm, M .A., O'Conner, K. (2005): Green infrastructure evaluation frameworks. - Journal of Conservation Planning 1: 6-25.

[24] McPherson, G., Simpson, J., Xiao, Q., Wu, C. (2008): Los Angeles 1-Million tree Canopy Cover Assessment. - USDA, Forest Service, general Technical Report, ref: PSWGTR- 207.

[25] Mell, I. C. (2016): GI management - time to 'let someone else have a go'? - Journal of the Town and Country Planning Association 8(1): 138-141.

[26] Pisano, U. (2012): Resilience and Sustainable Development: Theory of resilience, systems thinking and adaptive governance. - ESDN Quarterly Report 26.

[27] Sussams, L.W., Sheate, W.R., Eales, R.P. (2015): Green infrastructure as a climate change adaptation policy intervention: Muddying the waters or clearing a path to a more secure future? - Journal of Environmental Management 147(1): 184-193.

[28] UNDP. (2016): Egypt's National Strategy for Adaptation to Climate Change and Disaster Risk Reduction. 